\title{
A typical presentation of a hepatocellular carcinoma in a middle-aged patient
}

\author{
Rafael García Carretero, ${ }^{1}$ Oscar Vazquez-Gomez, ${ }^{1}$ Marta Romero Brugera, ${ }^{2}$ \\ Noelia Rebollo-Aparicio ${ }^{3}$
}

'Department of Internal Medicine, Hospital Universitario de Mostoles, Mostoles, Madrid, Spain

${ }^{2}$ Department of Emergency Medicine, Hospital Universitario de Mostoles, Mostoles, Madrid, Spain

${ }^{3}$ Department of Emergency Medicine, Hospital Rey Juan Carlos, Mostoles, Madrid, Spain

\section{Correspondence to}

Dr Rafael García Carretero, rgcarretero@salud.madrid.org

Accepted 16 August 2017

\section{DESCRIPTION}

A 54-year-old man was admitted to our hospital due to experiencing a sudden, severe pain in the right shoulder after mild exercise. He had been losing weight over the previous month and had noticed a lump near his right shoulder. A chest X-ray showed a lytic lesion in the lateral half of his right collarbone (figure 1A) with a cortical break and the presence of a soft-tissue component. A chest $\mathrm{CT}$ scan showed the destruction of the bone and a $10 \times 8 \times 7 \mathrm{~cm}$ mass associated with the pathological fracture of the collarbone (figure 1B). The diagnostic workup was completed with an abdominal CT scan, which showed a large hepatic tumour, an alpha-fetoprotein blood test level of $1468 \mathrm{ng} / \mathrm{mL}$ (normal range $<10 \mathrm{ng} / \mathrm{mL}$ ) and a fine-needle aspiration cytology, which yielded the final diagnosis of disseminated disease of a hepatocellular carcinoma. Cells showed both TTF-1 and hepatocyte antigen positivity, whereas CK7, CK20, CDX2 and p40 were negative.

Sorafenib $400 \mathrm{mg}$ twice daily was then started, but the patient developed intense malaise and hepatotoxicity 4 weeks after the treatment was initiated. Gamma-glutamyl transpeptidase levels were $1178 \mathrm{U} / \mathrm{L}$ (normal range 5-45 $\mathrm{U} / \mathrm{L}$ ), alanine transaminase was $234 \mathrm{U} / \mathrm{L}$ (normal range $5-30 \mathrm{U} / \mathrm{L}$ ), aspartate transaminase $156 \mathrm{U} / \mathrm{L}$, lactate dehydrogenase was $656 \mathrm{U} / \mathrm{L}$ (normal range 180-380 U/L) and bilirubin levels increased up to $15 \mathrm{mg} / \mathrm{dL}$. The treatment was discontinued, but the patient's condition worsened and he benefited from palliative care medicine. The patient passed away 5 months after the diagnosis.

Hepatocellular carcinoma is the most common type of liver cancer. Given this, screening is focused on regular determination of alpha-fetoprotein and
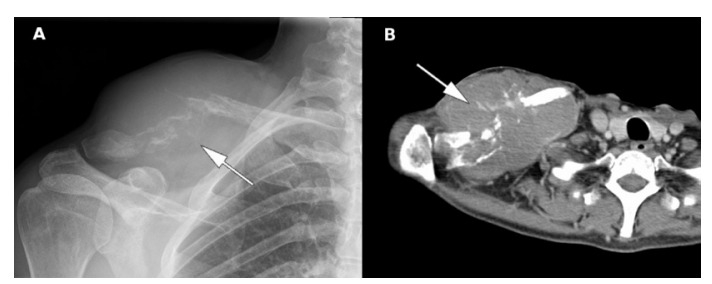

Figure 1 (A) Chest X-ray showing the lytic lesion of the right collarbone. (B) The collarbone was surrounded by a soft-tissue tumour, which broke the bone. abdominal ultrasound in patients with cirrhosis patients. In these patients, this tumour can occur in $5 \%-15 \%$ of cases. ${ }^{1}$ The most frequent site where hepatocellular carcinoma spreads is the portal vein, where this tumour can cause portal vein thrombosis. However, other less common metastasis locations are also possible, such as the lung, lymph nodes and bone. About $5 \%-7 \%$ of patients with hepatocellular carcinoma have bone metastases when the tumour is diagnosed. ${ }^{2}$

The clinical presentation in our patient was uncommon, as he did not have chronic viral hepatitis or cirrhosis. Furthermore, the first symptom was related to an uncommon spreading site, that is, the collarbone. The typical symptoms are related to chronic liver disease, such as ascites or jaundice. Other complications may arise due to the extension of the tumour to the portal vein. When these symptoms are not present, suspicion for hepatocellular carcinoma may be elusive.

\section{Learning points}

- Underlying liver disease, such as chronic viral hepatitis or cirrhosis, is the main risk factor for the development of this tumour.

- Since there are no pathognomonic symptoms, hepatocellular carcinoma may be diagnosed at a late stage, with a poor outcome.

- Patients with chronic viral hepatitis or cirrhosis should undergo regular determination of alpha-fetoprotein and abdominal ultrasound for screening purposes.

Contributors RGC wrote the first draft, OVG helped in the translation into English and MRB and NRA made interesting suggestions.

Competing interests None declared.

Patient consent Obtained.

Provenance and peer review Not commissioned; externally peer reviewed.

(C) BMJ Publishing Group Ltd (unless otherwise stated in the text of the article) 2017. All rights reserved. No commercial use is permitted unless otherwise expressly granted.

\section{REFERENCES}

1 Forner A, Llovet JM, Bruix J. Hepatocellular carcinoma. Lancet 2012;379:1245-55.

2 Bruix J, Sherman M. Management of hepatocellular carcinoma: an update. Hepatology 2011;53:1020-2. 
Copyright 2017 BMJ Publishing Group. All rights reserved. For permission to reuse any of this content visit http://group.bmj.com/group/rights-licensing/permissions.

BMJ Case Report Fellows may re-use this article for personal use and teaching without any further permission.

Become a Fellow of BMJ Case Reports today and you can:

- Submit as many cases as you like

- Enjoy fast sympathetic peer review and rapid publication of accepted articles

Access all the published articles

- Re-use any of the published material for personal use and teaching without further permission

For information on Institutional Fellowships contact consortiasales@bmjgroup.com

Visit casereports.bmj.com for more articles like this and to become a Fellow 